\title{
Integrated Weed Control Option for Dry Direct Seeded Rice under Irrigated Ecosystem
}

\author{
Suryakanta Kashyap $^{{ }^{*}}$, V.P. Singh ${ }^{1}$, S.K. Guru ${ }^{2}$, Tej Pratap ${ }^{1}$, \\ S.P. Singh ${ }^{1}$ and Subhashisa Praharaj ${ }^{1}$ \\ ${ }^{1}$ Department of Agronomy, ${ }^{2}$ Department of Plant Physiology, G. B. Pant University of \\ Agriculture \& Technology, Pantnagar, Uttarakhand - 263145, India \\ *Corresponding author
}

\section{Keywords}

Stale seedbed,

Conoweeder,

Brown manuring,

Pendimethalin,

Penoxsulam,

Handweeding

Article Info

Accepted:

04 January 2019

Available Online:

10 February 2019
A B S T R A C T

A field experiment was conducted during 2017-2018 at N. E. Borlaug Crop Research Centre of Govind Ballabh Pant University of Agriculture and Technology, Pantnagar, to study the integrated weed control option for dry Direct seeded Rice under irrigated ecosystem. Study reveals that stale seed bed with shallow tillage with pre-emergence application of pendimethalin followed by 1 mechanical weeding (MW) with conoweeder at 25 DAS along with $1 \mathrm{HW}$ at $45 \mathrm{DAS}$, Mulch followed by penoxsulam (PoE) followed by $1 \mathrm{HW}$ at 45 DAS, Sesbania line sowing with pre-emergence application of pendimethalin followed by $1 \mathrm{MW}$ followed by $1 \mathrm{HW}$ at 45 DAS and Stale seed bed with shallow tillage followed by Sesbania line sowing supplemented with pre-emergence application of pendimethalin followed by brown manuring with 2,4-D followed by $1 \mathrm{HW}$ at 45 DAS resulted lowed weed density (gassy, BLWs and sedges), weed biomass accumulation and higher WCE (\%) i.e. 90.2, 89.7, 89.3 and 88.1 respectively which were similar to recommended practice under $25 \mathrm{~cm}$ row to row spacing i.e. pre-emergence application of pendimethalin followed by post emergence application of penoxsulam supplemented with $1 \mathrm{HW}$ at 45 DAS. Higher benefit cost ratio was recorded under stale seed bed with shallow tillage with pre-emergence application of pendimethalin followed by 1 mechanical weeding (MW) with conoweeder at 25 DAS along with $1 \mathrm{HW}$ at 45 DAS, mulch followed by penoxsulam (PoE) followed by $1 \mathrm{HW}$ at 45 DAS and Sesbania line sowing with preemergence application of pendimethalin followed by $1 \mathrm{MW}$ followed by $1 \mathrm{HW}$ at 45 DAS. From the study it can be concluded that above three integrated practices were same effective as recommended practice for controlling weed with higher return.

\section{Introduction}

Rice (Oryza sativa L.) is one of the major cereal and staple food grain for about more than half of the world's population. An alternative to puddling and transplanting, direct seeding of rice requires less water, labour and energy inputs. The direct-seeded crop also matures earlier (7-10 days) than the transplanted rice, thus allowing timely 
planting of the succeeding crop. Weeds are the major biological constraint to the success of DSR in general and in particular to dryDSR (Rao et al., 2007). The trend for an increase in herbicide use has been reinforced by the spread of DSR. Application of different pre emergence herbicides including thiobencarb, pendimethalin, butachlor, oxadiazon and nitrofen has found to control weed satisfactorily in DSR. Among the different post emergence herbicides, ethoxy sulfuron, bispyribac sodium, cyahalofopbutyl, petrilachlor, chlorimuron, metsulfuron and penoxsulum were found effective against complex weed flora in DSR (Singh et al., 2007; Mahajan et al., 2009). However, the intensive use of herbicides pose selection pressure on ecosystem and leads to the evolution of resistant in weeds. Apart from chemical method, there are some other methods of weed control which can be employed. Intercropping of brown manuring crops with rice reduced weed densities by about 40-50 \% (Mahajan et al., 2009). In addition to brown manuring, stale seed bed technique can be integrated in weed control in direct seeded rice. So there is need to integrate other weed management strategies along with chemical control (Chahal et al., 2014, 2015). It has be found that herbicides in combination with other methods of weed control like physical and cultural result considerably superior weed control and better grain yield than the sole application due to their broad spectrum and long lasting weed control (Bhurer et al., 2013). To endow with more sustainable weed control measures and to protect the environment, reducing dependency on herbicides and applying cultural and physical measures in integrated with chemical weed management approaches, the experiment was conducted to study the effect of different weed management practices on weed dynamics and yield of dry Direct Seeded Rice under irrigated ecosystem.

\section{Materials and Methods}

The field experiment was conducted at Norman E. Borlaug Crop Research Center of G.B. Pant University of Agriculture and Technology Pantnagar, District of Udham Singh Nagar (Uttarakhand) during 'kharif' season of 2017. This centre is situated at an altitude of 243.84 metres above mean sea level, $29^{\circ} \mathrm{N}$ latitude and $79.3^{\circ} \mathrm{E}$ longitudes lies at the foot hills of "Shivalik" ranges of Himalaya, a narrow belt called "Tarai" where the climate is subtropical. The soil of the experimental site is clay loam texture,

The experiment was laid out in randomized block design with twelve treatments $\left(\mathrm{T}_{1}\right.$-stale seed bed with shallow tillage followed by post emergence application of penoxsulam $(\mathrm{PoE})$ at $22.5 \mathrm{~g} / \mathrm{ha}, \mathrm{T}_{2}$-stale seed bed with shallow tillage followed by pre emergence application of pendimethalin (PE) at $1000 \mathrm{~g} / \mathrm{ha}$ along with 1 hand weeding (HW) 30DAS, $\mathrm{T}_{3}$-stale seed bed with shallow tillage followed by preemergence application of pendimethalin followed by 1 mechanical weeding (MW) with conoweeder at 25 DAS along with $1 \mathrm{HW}$ at $45 \mathrm{DAS}, \mathrm{T}_{4}$-mulch (wheat straw of $4 \mathrm{t} / \mathrm{ha}$ ) followed by post emergence application of penoxsulam at $22.5 \mathrm{~g} / \mathrm{ha}$ followed by $1 \mathrm{HW}$ at 45 DAS, T5-post emergence application of penoxsulam at $22.5 \mathrm{~g} / \mathrm{ha}$ followed by $1 \mathrm{HW}$ at 45 DAS, $\mathrm{T}_{6}$-Sesbania line sowing with preemergence application of pendimethalin followed by 1 mechanical weeding 1t 25 DAS followed by $1 \mathrm{HW}$ at $45 \mathrm{DAS}, \mathrm{T}_{7}$-Sesbania broadcasting followed by brown manuring with 2,4-D at $500 \mathrm{~g} / \mathrm{ha}$ along with $1 \mathrm{HW}$ at 45 DAS, $T_{8}$-stale seed bed with shallow tillage followed by Sesbania line sowing followed by pre-emergence pendimethalin followed by brown manuring with 2,4-D at $500 \mathrm{~g} / \mathrm{ha}$ followed by $1 \mathrm{HW}$ at $45 \mathrm{DAS}, \mathrm{T}_{9}$-pre emergence application of pendimethalin followed by penoxsulam (PoE) followed by 1HW 45 DAS, $\mathrm{T}_{10^{-}}$pre-emergence 
application of pendimethalin followed by penoxsulam (PoE) followed by 1HW 45 DAS $(20 \mathrm{~cm}), \mathrm{T}_{11}$-weedy check and $\mathrm{T}_{12}$-weedy free) which were replicated thrice. All the treatments were in $25 \mathrm{~cm}$ except one.

After harvesting of wheat, the field was prepared by two harrowing and levelling and after that 5-6 cm depth of irrigation was provided in the field. About 2 irrigations was provided in the field which allowed the weed seed to germinate. At $12^{\text {th }}$ days germinated weed seedlings were ploughed by shallow tillage by power tiller. Rice seeds of 'Govind' variety was sown on 13th June, 2017 in lines at seed rate of $40 \mathrm{~kg} / \mathrm{ha}$ with a spacing of 25 $\mathrm{cm}$ apart manually in all plots and in one treatment $\left(T_{10}\right)$ recommended row to row spacing of $20 \mathrm{~cm}$ was maintained. For brown manuring, seeds of Sesbania were alternatively grown with rice at the seed rate of $40 \mathrm{~kg} / \mathrm{ha}$. And in case of broadcasting, seeds were broadcasted before sowing of rice on the same day. Crop was fertilized with 120: $60: 40 \mathrm{~kg} / \mathrm{ha}$ of $\mathrm{N}, \quad \mathrm{P}_{2} \mathrm{O}_{5}, \quad \mathrm{~K}_{2} \mathrm{O}$, respectively in the experimental area. Observations on weeds were recorded by placing the quadrate of size $25 \mathrm{~cm} \times 25 \mathrm{~cm}$. Weed control efficiency (WCE) was calculated by using the formula,

$\mathrm{WCE}(\%)=\frac{\mathrm{WD}_{\mathrm{C}}-\mathrm{WD}_{\mathrm{T}}}{\mathrm{WD}_{\mathrm{C}}} \times 100$

Where,

$\mathrm{WD}_{\mathrm{C}}=$ Weed dry weight in control plot

$\mathrm{WD}_{\mathrm{T}}=$ Weed dry weight in treated plot

\section{Results and Discussion}

\section{Effect on weeds}

\section{Weed density}

Major weeds in experimental field were Echinochloa cruss-galli, Echinochloa colona and Leptochloa chinensis among grassy weed; Cyperus iria and Cyperus difformis among sedges; Ammania baccifera and Alternanthera sessilis among broadleaf weeds. Lower weed density (grassy and BLWs) obtained with recommended practice under narrower spacing $\left(T_{10}\right)$ followed by recommended practice under wider spacing $\left(\mathrm{T}_{10}\right)$. Also recommended practice with wider spacing $\left(\mathrm{T}_{9}\right)$ was statistically at par with stale seed bed followed by shallow tillage followed by pre-emergence application of pendimethalin at $1000 \mathrm{~g} / \mathrm{ha}$ followed by 1 mechanical weeding at 25 DAS with conoweeder along with $1 \mathrm{HW}$ at $45 \mathrm{DAS}\left(\mathrm{T}_{3}\right)$, line sown Sesbania integrated with preemergence application of pendimethalin at $1000 \mathrm{~g} / \mathrm{ha}$ followed by $1 \mathrm{MW}$ at $25 \mathrm{DAS}$ along with $1 \mathrm{HW}$ at 45 DAS $\left(\mathrm{T}_{6}\right)$, mulching integrated with post-emergence application of penoxsulam at $22.5 \mathrm{~g} /$ ha followed by $1 \mathrm{HW}$ at 45 DAS $\left(T_{4}\right)$ and stale seed bed followed by shallow tillage along with line sown Sesbania followed by pre-emergence application of pendimethalin at $1000 \mathrm{~g} / \mathrm{ha}$ followed by postemergence application of 2,4-D at $500 \mathrm{~g} / \mathrm{ha}$ supplemented with $1 \mathrm{HW}$ at $45 \mathrm{DAS}\left(\mathrm{T}_{8}\right)$. All the integrated approached resulted minimum density of sedges except integration of stale seed bed along either alone post-emergence application of penoxsulam or pre-emergence application of pendimethalin along with 1 $\mathrm{HW}$ at $30 \mathrm{DAS}\left(\mathrm{T}_{1}\right.$ and $\left.\mathrm{T}_{2}\right)$.

In stale seed bed, weeds are allowed to germinate by giving a light irrigation or after a rainfall and after that emerged weed seedlings were killed by shallow tillage which effectively reduces weed emergence and the number of weed seeds in the soil seed bank also facilitate better crop growth during initial stages (Rao et al., 2007). Effect of different weed management practices on weed density $\left(\mathrm{No} . / \mathrm{m}^{2}\right)$ of different weed species at 60 days of crop growth is given in Table 1. 


\section{Weed biomass}

Among all the integrated approaches, recommended practice under narrower spacing $\left(\mathrm{T}_{10}\right)$ resulted lower weed biomass (grassy, BLWs and sedges) followed by recommended practice under wider spacing $\left(\mathrm{T}_{9}\right)$. This $\left(\mathrm{T}_{9}\right)$ was statistically at par with stale seed bed followed by shallow tillage followed by pre-emergence application of pendimethalin at $1000 \mathrm{~g} / \mathrm{ha}$ followed by 1 mechanical weeding at 25 DAS with conoweeder along with $1 \mathrm{HW}$ at $45 \mathrm{DAS}\left(\mathrm{T}_{3}\right)$, line sown Sesbania integrated with preemergence application of pendimethalin at $1000 \mathrm{~g} / \mathrm{ha}$ followed by $1 \mathrm{MW}$ at $25 \mathrm{DAS}$ along with $1 \mathrm{HW}$ at $45 \mathrm{DAS}\left(\mathrm{T}_{6}\right)$, mulching integrated with post-emergence application of penoxsulam at $22.5 \mathrm{~g} / \mathrm{ha}$ followed by $1 \mathrm{HW}$ at 45 DAS $\left(\mathrm{T}_{4}\right)$ and stale seed bed followed by shallow tillage along with line sown Sesbania followed by pre-emergence application of pendimethalin at $1000 \mathrm{~g} / \mathrm{ha}$ followed by postemergence application of $2,4-\mathrm{D}$ at $500 \mathrm{~g} / \mathrm{ha}$ supplemented with $1 \mathrm{HW}$ at $45 \mathrm{DAS}\left(\mathrm{T}_{8}\right)$. The reduction of the weed population and biomass accumulation during crop growth period with stale seedbed technique which reduces the early seed flushes, in combination with mechanical weeding was found as effective as chemical control (Rie et al., 2007). Similar result was also observed by Verma et al., (2017) observed that among non - chemical methods of weed control, Sesbania co-culture followed by conoweeder (25 DAS) followed by $1 \mathrm{HW}$ resulted lower weed density, lower weed dry matter accumulation, highest WCE, higher grain yield in aerobic rice. Effect of different weed management practices on weed dry matter accumulation $\left(\mathrm{g} / \mathrm{m}^{2}\right)$ of different weed species at 60 days of crop growth is given in Table 2.

\section{Weed Control Efficiency (WCE)}

Highest WCE (100\%) was recorded in weed free condition and lowest in weedy check condition. This was in accordance with the findings of Singh et al., 2006 and Saha and Rao, 2009. Recommended practice under narrower spacing $\left(T_{10}\right)$ resulted higher WCE because of lower weed biomass accumulation followed by recommended practice under wider spacing $\left(\mathrm{T}_{9}\right)$. This $\left(\mathrm{T}_{9}\right)$ was being similar WCE as stale seed bed followed by shallow tillage followed by pre-emergence application of pendimethalin at $1000 \mathrm{~g} / \mathrm{ha}$ followed by 1 mechanical weeding at 25 DAS with conoweeder along with $1 \mathrm{HW}$ at $45 \mathrm{DAS}$ $\left(\mathrm{T}_{3}\right)$, line sown Sesbania integrated with preemergence application of pendimethalin at $1000 \mathrm{~g} / \mathrm{ha}$ followed by $1 \mathrm{MW}$ at $25 \mathrm{DAS}$ along with $1 \mathrm{HW}$ at $45 \mathrm{DAS}\left(\mathrm{T}_{6}\right)$, mulching integrated with post-emergence application of penoxsulam at $22.5 \mathrm{~g} / \mathrm{ha}$ followed by $1 \mathrm{HW}$ at 45 DAS $\left(\mathrm{T}_{4}\right)$ and stale seed bed followed by shallow tillage along with line sown Sesbania followed by pre-emergence application of pendimethalin at $1000 \mathrm{~g} / \mathrm{ha}$ followed by postemergence application of 2,4-D at $500 \mathrm{~g} / \mathrm{ha}$ supplemented with $1 \mathrm{HW}$ at $45 \mathrm{DAS}\left(\mathrm{T}_{8}\right)$ because of similar weed biomass accumulation. Effect of different weed management practices on Weed control efficiency (\%) in given in Table 3.

\section{Crop yield}

Highest grain yield (4.4 t/ha) was recorded in the weed free condition which was statistically at par with the treatments; recommended practice with wider row spacing $\left(\mathrm{T}_{9}\right)$ stale seed bed followed by shallow tillage followed by pre-emergence application of pendimethalin at $1000 \mathrm{~g} / \mathrm{ha}$ followed by 1 mechanical weeding at 25 DAS with conoweeder along with $1 \mathrm{HW}$ at 45 DAS $\left(\mathrm{T}_{3}\right)$, mulching integrated with postemergence application of penoxsulam at 22.5 $\mathrm{g} /$ ha followed by $1 \mathrm{HW}$ at $45 \mathrm{DAS}\left(\mathrm{T}_{4}\right)$, line sown Sesbania integrated with pre-emergence application of pendimethalin at $1000 \mathrm{~g} / \mathrm{ha}$ followed by $1 \mathrm{MW}$ at $25 \mathrm{DAS}$ along with 1 
HW at 45 DAS $\left(T_{6}\right)$ and stale seed bed followed by shallow tillage along with line sown Sesbania followed by pre-emergence application of pendimethalin at $1000 \mathrm{~g} / \mathrm{ha}$ followed by post-emergence application of 2,4-D at $500 \mathrm{~g} / \mathrm{ha}$ supplemented with $1 \mathrm{HW}$ at 45 DAS $\left(T_{8}\right)$. This was due to lower weed biomass accumulation which results in higher weed control efficiency. Similar result were also suggested by Gaire et al., 2013 that Sesbania co-culture technology reduces the weed population by nearly about $50 \%$ with no adverse effect on rice yield as comprise of growing of rice and sesbania together and then killing Sesbania with 2, 4-D as it provide smootering effect on weed and also use of 2,4-D effectively controls the broadleaf weeds. Also inclusion of mechanical weeding by conoweeder not only provided better weed control in inter rows but also provided aeration in soil root zone resulting better root growth and tillering and finally the better crop yield (Kumar et al., 2012). Effect of different weed management practices on grain yield (t/ha) is given in Table 3.

Table.1 Effect of different weed management practices on weed density $\left(\right.$ No. $\left./ \mathrm{m}^{2}\right)$ of different weed species at 60 days of crop growth

\begin{tabular}{|c|c|c|c|c|c|}
\hline Sl.No. & Treatment & Dose (g/ha) & Grassy & BLWs & Sedges \\
\hline $\mathbf{T}_{1}$ & SSB $f b$ penoxsulam $(\mathrm{PoE})$ & 22.5 & $\begin{array}{c}7.1 \\
(50.0)\end{array}$ & $4.4(18.7)$ & $3.6(12)$ \\
\hline $\mathbf{T}_{2}$ & SSB $f b$ pendimethalin (PE) $f b 1$ HW 30 DAS & 1000 & $\begin{array}{c}6.6 \\
(42.7)\end{array}$ & $3.9(14.7)$ & $3.4(10.7)$ \\
\hline $\mathbf{T}_{3}$ & $\begin{array}{l}\text { SSB } f b \text { Pendimethalin (PE) } f b 1 \mathrm{MW} f b 1 \mathrm{HW} \\
45 \mathrm{DAS}\end{array}$ & 1000 & $\begin{array}{c}3.4 \\
(10.7)\end{array}$ & $2.5(5.3)$ & $1.0(0)$ \\
\hline $\mathbf{T}_{\mathbf{4}}$ & Mulch $f b$ penoxsulam (PoE) $f b$ 1HW 45 DAS & 22.5 & $\begin{array}{c}3.7 \\
(13.3)\end{array}$ & $2.8(6.7)$ & $1.0(0)$ \\
\hline $\mathbf{T}_{5}$ & Penoxsulam (PoE) fb 1HW 45 DAS & 22.5 & $\begin{array}{c}4.3 \\
(17.3)\end{array}$ & $3.0(8.0)$ & $1.0(1.0)$ \\
\hline $\mathbf{T}_{6}$ & $\begin{array}{l}\text { Sesbania (LS) + Pendimethalin (PE) } f b 1 \mathrm{MW} \\
25 \text { DAS } f b \text { 1HW } 45 \text { DAS }\end{array}$ & 1000 & $\begin{array}{c}3.6 \\
(12.0)\end{array}$ & $2.5(5.3)$ & $1.0(0)$ \\
\hline $\mathbf{T}_{7}$ & $\begin{array}{l}\text { Sesbania (BC) brown manuring with 2,4-D } \\
f b 1 \text { HW } 45 \text { DAS }\end{array}$ & 500 & $\begin{array}{c}4.3 \\
(17.3)\end{array}$ & $3.0(8.0)$ & $1.0(0)$ \\
\hline $\mathbf{T}_{8}$ & $\begin{array}{l}\text { SSB } f b \text { Sesbania }(\mathrm{LS}) f b \text { pendimethalin (PE) } \\
f b \text { 2,4-D (PoE) } 1 \text { HW } 45 \text { DAS }\end{array}$ & $\begin{array}{c}1000+ \\
500\end{array}$ & $\begin{array}{c}3.9 \\
(14.7)\end{array}$ & $2.5(5.3)$ & $1.0(0)$ \\
\hline $\mathbf{T}_{9}$ & $\begin{array}{l}\text { Pendimethalin (PE) } f b \text { Penoxsulam (PoE) } f b 1 \\
\text { HW } 45 \text { DAS }\end{array}$ & $\begin{array}{c}1000+ \\
22.5\end{array}$ & $\begin{array}{c}3.4 \\
(10.7)\end{array}$ & $2.5(5.3)$ & $1.0(0)$ \\
\hline $\mathbf{T}_{10}$ & $\begin{array}{l}\text { Pendimethalin (PE) } f b \text { Penoxsulam (PoE) } f b 1 \\
\text { HW (20cm) } 45 \text { DAS }\end{array}$ & $\begin{array}{c}1000+ \\
22.5\end{array}$ & $2.5(5.3)$ & $1.9(2.7)$ & $1.0(0)$ \\
\hline $\mathbf{T}_{11}$ & Weedy check & & $\begin{array}{c}10.8 \\
(116.0)\end{array}$ & $9.4(87.3)$ & $6.6(42.7)$ \\
\hline $\mathbf{T}_{12}$ & Weed free & & $1.0(0)$ & $1.0(0)$ & $1.0(0)$ \\
\hline \multicolumn{2}{|r|}{ SEm \pm} & & 0.31 & 0.20 & 0.06 \\
\hline \multicolumn{2}{|r|}{ C.D. $(5 \%)$} & & 0.9 & 0.6 & 0.2 \\
\hline
\end{tabular}

Original values are given in parenthesis (SSB - stale seed bed with shallow tillage at 12 DAS, BC- broadcasting, LSLine sowing, HW- Hand weeding, MW- Mechanical weeding with conoweeder, PoE- Post-emergence, PE- Pre emergence

* In all treatments wider row spacing $(25 \mathrm{~cm})$ except in $\mathrm{T}_{10}$ where close spacing $(20 \mathrm{~cm})$ was maintained 
Table.2 Effect of different weed management practices on weed dry matter accumulation $\left(\mathrm{g} / \mathrm{m}^{2}\right)$ of different weed species at 60 days of crop growth

\begin{tabular}{|c|c|c|c|c|c|c|}
\hline Sl.No. & Treatment & $\begin{array}{l}\text { Dose } \\
\text { (g/ha) }\end{array}$ & Grassy & BLWs & Sedges & Total \\
\hline $\mathbf{T}_{1}$ & $\mathrm{SSB} f b$ penoxsulam $(\mathrm{PoE})$ & 22.5 & $\begin{array}{c}6.3 \\
(38.1)\end{array}$ & $\begin{array}{c}5.1 \\
(25.4)\end{array}$ & $\begin{array}{c}3.5 \\
(11.4)\end{array}$ & $\begin{array}{c}8.7 \\
(11.4)\end{array}$ \\
\hline $\mathbf{T}_{2}$ & $\begin{array}{l}\text { SSB } f b \text { pendimethalin (PE) } f b 1 \mathrm{HW} 30 \\
\text { DAS }\end{array}$ & 1000 & $\begin{array}{c}5.9 \\
(34.4)\end{array}$ & $\begin{array}{c}4.9 \\
(23.3)\end{array}$ & $\begin{array}{c}3.2 \\
(9.3)\end{array}$ & $8.2(9.3)$ \\
\hline $\mathbf{T}_{\mathbf{3}}$ & $\begin{array}{l}\text { SSB } f b \text { Pendimethalin }(\mathrm{PE}) f b 1 \mathrm{MW} f b \\
1 \mathrm{HW} 45 \text { DAS }\end{array}$ & 1000 & $\begin{array}{c}3.5 \\
(11.1)\end{array}$ & $\begin{array}{c}3.2 \\
(9.2)\end{array}$ & $1.0(0)$ & $\begin{array}{c}4.6 \\
(20.3)\end{array}$ \\
\hline $\mathbf{T}_{4}$ & $\begin{array}{l}\text { Mulch } f b \text { penoxsulam }(\mathrm{PoE}) f b 1 \mathrm{HW} \\
45 \text { DAS }\end{array}$ & 22.5 & $\begin{array}{c}3.6 \\
(11.7)\end{array}$ & $\begin{array}{c}3.2 \\
(9.6)\end{array}$ & $1.0(0)$ & $\begin{array}{c}4.7 \\
(21.3)\end{array}$ \\
\hline $\mathbf{T}_{5}$ & Penoxsulam (PoE) $f b$ 1HW 45 DAS & 22.5 & $\begin{array}{c}4.2 \\
(16.4)\end{array}$ & $\begin{array}{c}3.6 \\
(12.6)\end{array}$ & $1.0(0)$ & $\begin{array}{c}5.4 \\
(28.4)\end{array}$ \\
\hline $\mathbf{T}_{6}$ & $\begin{array}{l}\text { Sesbania (LS) + Pendimethalin (PE) } \\
f b 1 \mathrm{MW} 25 \mathrm{DAS} f b \text { 1HW } 45 \mathrm{DAS}\end{array}$ & 1000 & $\begin{array}{c}3.6 \\
(11.9)\end{array}$ & $\begin{array}{c}3.3 \\
(10.2)\end{array}$ & $1.0(0)$ & $\begin{array}{c}4.8 \\
(22.1)\end{array}$ \\
\hline $\mathbf{T}_{7}$ & $\begin{array}{l}\text { Sesbania (BC) brown manuring with } \\
\text { 2,4-D fb1 HW } 45 \text { DAS }\end{array}$ & 500 & $\begin{array}{c}4.1 \\
(15.9)\end{array}$ & $\begin{array}{c}3.4 \\
(10.9)\end{array}$ & $1.0(0)$ & $\begin{array}{c}5.3 \\
(26.8)\end{array}$ \\
\hline $\mathbf{T}_{8}$ & $\begin{array}{l}\text { SSB } f b \text { Sesbania (LS) } f b \text { pendimethalin } \\
\text { (PE) } f b 2,4-\mathrm{D} \text { (PoE) } 1 \mathrm{HW} 45 \mathrm{DAS}\end{array}$ & $\begin{array}{c}1000+ \\
500\end{array}$ & $\begin{array}{c}3.9 \\
(14.2)\end{array}$ & $\begin{array}{c}3.4 \\
(10.3)\end{array}$ & $1.0(0)$ & $\begin{array}{c}5.0 \\
(24.5)\end{array}$ \\
\hline $\mathbf{T}_{9}$ & $\begin{array}{l}\text { Pendimethalin (PE) } f b \text { Penoxsulam } \\
\text { (PoE) } f b 1 \text { HW } 45 \text { DAS }\end{array}$ & $\begin{array}{c}1000+ \\
22.5\end{array}$ & $\begin{array}{c}3.4 \\
(10.5)\end{array}$ & $\begin{array}{c}3.1 \\
(8.9)\end{array}$ & $1.0(0)$ & $\begin{array}{c}4.5 \\
(19.3)\end{array}$ \\
\hline $\mathbf{T}_{10}$ & $\begin{array}{l}\text { Pendimethalin (PE) } f b \text { Penoxsulam } \\
(\mathrm{PoE}) f b 1 \mathrm{HW}(20 \mathrm{~cm}) 45 \text { DAS }\end{array}$ & $\begin{array}{c}1000+ \\
22.5\end{array}$ & $\begin{array}{c}3.1 \\
(8.6)\end{array}$ & $\begin{array}{c}2.2 \\
(4.0)\end{array}$ & $1.0(0)$ & $\begin{array}{c}3.7 \\
(12.6)\end{array}$ \\
\hline $\mathbf{T}_{11}$ & Weedy check & & $\begin{array}{l}9.9 \\
(97)\end{array}$ & $\begin{array}{c}9.4 \\
(87.3)\end{array}$ & $\begin{array}{c}4.6 \\
(20.4)\end{array}$ & $\begin{array}{c}14.4 \\
(206.5 .8)\end{array}$ \\
\hline $\mathbf{T}_{12}$ & Weed free & & $1.0(0)$ & $1.0(0)$ & $1.0(0)$ & $1.0(0)$ \\
\hline & SEm \pm & & 0.25 & 0.16 & 0.11 & 0.33 \\
\hline & C.D. $(5 \%)$ & & 0.7 & 0.5 & 0.3 & 1.0 \\
\hline
\end{tabular}

Original values are given in parenthesis (SSB - stale seed bed with shallow tillage at 12 DAS, BC- broadcasting, LSLine sowing, HW- Hand weeding, MW- Mechanical weeding with conoweeder, PoE- Post-emergence, PE- Pre emergence

* In all treatments wider row spacing $(25 \mathrm{~cm})$ except in $\mathrm{T}_{10}$ where close spacing $(20 \mathrm{~cm})$ was maintained 
Table.3 Effect of different weed management practices on Weed control efficiency (\%), grain yield (t/ha) and B:C ratio

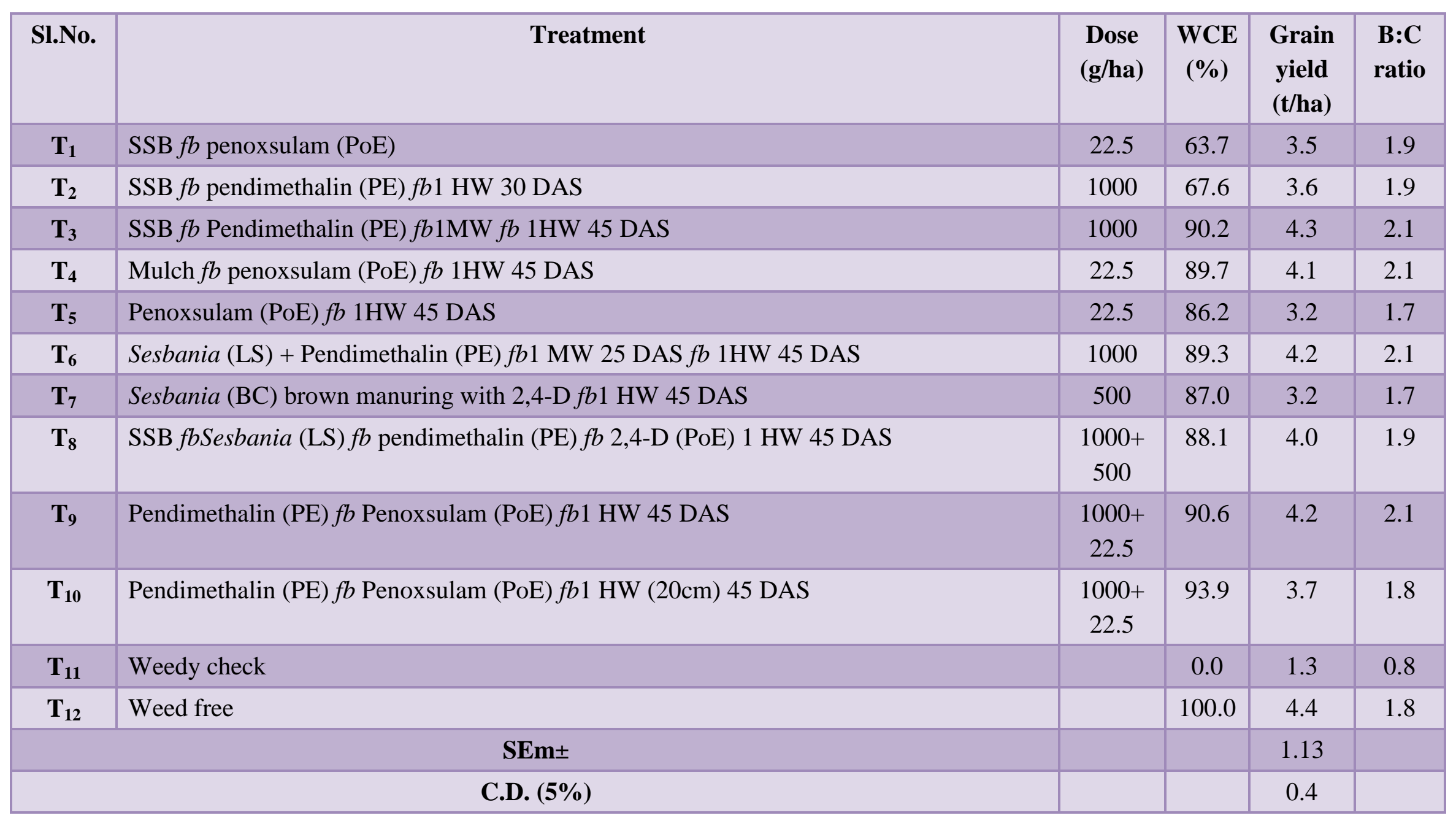

(SSB - stale seed bed with shallow tillage at 12 DAS, BC- broadcasting, LS- Line sowing, HW- Hand weeding, MW- Mechanical weeding with conoweeder, PoE- Post-emergence, PE- Pre emergence

* In all treatments wider row spacing $(25 \mathrm{~cm})$ except in $\mathrm{T}_{10}$ where close spacing $(20 \mathrm{~cm})$ was maintained. 


\section{Economics}

Benefit cost ratio was found highest (2.1) under recommended practice with wider spacing of $25 \mathrm{~cm}\left(\mathrm{~T}_{9}\right)$ which was similar with stale seed bed followed by shallow tillage followed by pre-emergence application of pendimethalin at $1000 \mathrm{~g} / \mathrm{ha}$ followed by 1 MW at 25 DAS with conoweeder supplemented with $1 \mathrm{HW}$ at $45 \mathrm{DAS}\left(\mathrm{T}_{3}\right)$, mulch followed by post-emergence application of penoxsulam at $22.5 \mathrm{~g} / \mathrm{ha}$ along with $1 \mathrm{HW}$ at $45 \mathrm{DAS}\left(\mathrm{T}_{4}\right)$ and Sesbania line sowing with pre-emergence application of pendimethalin at $1000 \mathrm{~g} / \mathrm{ha}$ followed by 1 MW at 25 DAS along with $1 \mathrm{HW}$ at 45 DAS $\left(\mathrm{T}_{6}\right)$. This might be resulted due to lower cost of cultivation and higher grain yield which resulted higher return. Effect of different weed management practices on $\mathrm{B}: \mathrm{C}$ ratio of crop is given in Table 3 .

Based on findings of the present investigation, it is concluded that pre emergence application of pendimethalin followed by post-emergence application of penoxsulam followed by 1 hand weeding (45 DAS) under $25 \mathrm{~cm}$ resulted higher grain yield as compared to crop with same of weed control practice under $20 \mathrm{~cm}$ spacing.

However satisfactory weed management and similar rice yields can be achieved by combination of stale seed bed technique integrated with pre-emergence application of pendimethalin herbicide along with mechanical weeding, pre-emergence application of pendimethalin herbicide with Sesbania brown manuring with mechanical weeding and hand weeding at 45 DAS and wheat straw mulch with PoE application of penoxsulam followed by 1 hand weeding at 45 DAS. All these IWM practices have similar benefit cost ratio. So, farmers can choose any of these IWM packages for weed management in dry DSR which suits them best.

\section{Acknowledgement}

Support from Dr. V. P. Singh, Professor, Department of Agronomy, College of Agriculture, GBPUAT, Pantnagar is gratefully acknowledged.

\section{References}

Bhurer, K. P., Yadav, D. N., Ladha, J. K., Thapa, R. B and Pandey K. R. 2013. Effect of integrated weed management practices on performance of dry direct seeded rice. Agronomy Journal of Nepal 3:53-63.

Chahal, P. S. 2014. Efficacy of preemergence and post- emergence soybean herbicides for control of glufosinate, glyphosate and imidazolinone-resistant volunteer corn. J. Agric. Sci. 6: 131-140.

Chahal, P. S., Jhala, A. J. 2015. Herbicide programs for control of glyphosate resistant volunteer corn in glufosinate resistant soybean. Weed Technol. 29(3): 431-443.

Gaire, R., Dahal, K. R., and Amgain, L. P. 2013. Effect of different mulching materials on weed dynamics and yield of direct seeded rice in Chitwan, Nepal. Agron J Nepal 3:73- 81.

Johnson, D. E. and A. M. Mortimer. 2005. Issues for integrated weed management and decision support in direct-seeded rice. Rice Is Life. 23: 211-214.

Kumar, J. Singh, D., Singh, B., Singh, R., Pawar, S and Gupta, K. 2012. Sowing time and weed management practices to enhance yield of direct seeded rice. Indian J. Weed. Sci. 44 (4) 207-209.

Mahajan, G. Chauhan, B. S. and Johnson, D. E. 2009. Weed management in aerobic rice in north western Indo-Gangetic Plains. J Crop Imp 23: 366-82.

Rao, A. N., Johnson, D. E., Sivaprasad, B., 
Ladha, J. K. and Mortimer, A. M. 2007. Weed management in directseeded rice. Adv Agron 93: 153-255.

Saha, S. and Rao, K. S. 2009. Efficacy of sulfonylurea herbicides for broadspectrum weed control in wet directsown summer rice. Oryza, 46 (2): 116119.

Singh, K. and Mahajan, G. and Timsina, J. 2011. Performance and water-use efficiency of rice cultivars to establishment methods in Northwestern Indo - Gangetic Plains. J Cro Imp 25(5): 597-617.

Singh, P., Singh, P. and Singh, S.S. 2007. Response of aromatic rice to establishment methods, fertility levels and weed management practices. Indian Journal of Weed Science. 39 (1 \& 2): 32-35.

Singh, V.P., Singh, R.P. and Singh, Y. 2006. Integrated weed management in direct dry seeded rainfed lowland rice. Indian J. Weed Sci., 38 (1\&2): 49-53.

Verma, H., Singh, S.P., Singh, V.P., Mahapatra, B.S., Sirazuddin, Joshi, N and Chilwal, A. 2017. Weed dynamics of aerobic Rice (Oryza sativa L.) under chemical and non-Chemical weed management practices in Irrigated Ecosystem. Int.J.Curr. Microbiol.App.Sci. 6(12): 3159-3165.

\section{How to cite this article:}

Suryakanta Kashyap, V.P. Singh, S.K. Guru, Tej Pratap, S.P. Singh and Subhashisa Praharaj. 2019. Integrated Weed Control Option for Dry Direct Seeded Rice under Irrigated Ecosystem. Int.J.Curr.Microbiol.App.Sci. 8(02): 315-323. doi: https://doi.org/10.20546/ijcmas.2019.802.037 